\title{
Japaninsuomalaisten kielikäsitykset
}

Liisa-Maria Lehto: Korpusavusteinen diskurssianalyysi japaninsuomalaisten kielipuheesta. Acta Universitatis Ouluensis B, Humaniora 162. Oulu: Oulun yliopisto 2018. 274 s. + liitteet 42 s. ISBN 978-952-621909-7. Väitöskirja on luettavissa osoitteessa http://urn.fi/urn:isbn:9789526219097.

Liisa-Maria Lehto käsittelee monografiaväitöskirjassaan Korpusavusteinen diskurssianalyysi japaninsuomalaisten kielipuheesta varsin spesifiä informanttijoukkoa, japaninsuomalaisia, ja heidän tapojaan puhua suomen, japanin ja englannin kielestä. Japaninsuomalaiset ovat kiinnostava tutkimuskohde siirtolaisuuden ja maahanmuuton sekä monikulttuuristumisen ja monikielistymisen näkökulmista, eikä tällaista ryhmää ole ennen tutkittu juuri lainkaan.

Sosiolingvistiikan kentässä Lehdon väitöskirjan pääasiallinen tieteellinen merkitys liittyy vapaasti yksilöinä liikkuvien ekspatriaattien tutkimukseen, ei esimerkiksi yhteisöjen tai vähemmistöjen kuvaukseen. Tieteellisesti kiinnostavaa tutkimuksessa on myös Japanin kaltainen moderni yhteiskunta, sillä sitä on pidetty poliittis-ideologisesti homogeenisenä ja yksikielisenä. Tästä ja lähtömaa Suomen kontekstista kumpuavat informanttien kieliasenteita ja -käsityksiä heijastelevat diskurssit, joihin Lehto pureutuu laadullista analyysiä ja korpustutkimusta yhdistelevin menetelmin. Japaninsuomalaisia peilataan sekä muihin vähemmistöihin ja siirtolaisuuden muutokseen Japanissa että suomalaissiirtolai- suuteen informanttien lähtömaan kontekstissa.

Väitöskirjan tavoite on kaksijakoinen: yhtäältä selvitetään, miten japaninsuomalaiset puhuvat kielestä, toisaalta, miten näitä diskursseja voidaan analysoida korpusmenetelmillä.

Lehto on tehnyt kenttätyötä Japanissa ja kerännyt aineistonsa haastattelemalla joukkoa japaninsuomalaisia. Informantit eivät muodosta erityistä omaa koherenttia joukkoaan - saati yhteisöä. Pikemminkin kyse on ryhmästä, joka koostuu yksittäisistä henkilöistä. Informantteja on kaikkiaan 14, ja he ovat osallistuneet sekä yksilöhaastatteluihin että parikeskusteluihin. Ä̈nitettyä aineistoa on kaikkiaan 24 tuntia. Toivoa sopii, että aineisto on jatkossa myös muiden tutkijoiden käytettävissä.

\section{Sosiolingvistiikkaa diskurssianalyysin ja korpustutkimuksen keinoin}

Väitöskirjan johdannossa Lehto kehystää tutkimusongelmansa kuvaamalla globalisaatiokehityksen tuomaa siirtolaisuuden muutosta ja moninaisuutta. Luku onkin käyttökelpoinen kooste siitä, miten globalisaation ja siirtolaisuuden kysymyksiä on käsitelty sosiolingvistisen monikielisyystutkimuksen laajalla kentällä. Lehto luo yleiskuvaa etenkin kielikäsitysten, -asenteiden, -identiteettien ja -ideologioiden tutkimuksesta sekä yleisemmin kielen ja kulttuurin suhteeseen liittyvistä kysymyksenasetteluista.

Siirtolaisuuden moninaisuuden Lehto kytkee uusimpaan liikkuvuutta käsitte- 
levään tutkimuskenttään (tai -kenttiin) ja sitä myötä esimerkiksi Vertovecin (2007), Blommaertin ja Ramptonin (2011; ks. myös Blommaert \& Backus 2012) 200o-luvulla käyttämään superdiversiteetin käsitteeseen. Näistä sekä Blommaert että Rampton keskittyvät erityisesti urbaaneihin monikielisiin kielenkäytön konteksteihin. Lehdon informanteista taas osa asuu Japanissa pikkupaikkakunnilla tai jopa maaseutumaisessa ympäristössä, joten tältä osin kytkös alan aiempaan tutkimukseen jää työssä hieman ohueksi. Tosin transnationaalisuus eri muodoissaan koskettaa kaikkea siirtolaisuuden tutkimusta; työssä olisikin ollut hyvä avata kielellisen resurssin käsite ja sen taustat laajemmin.

Lehto yhdistää aineistonsa analyysissä korpusmenetelmiä ja diskurssintutkimusta. Diskurssintutkimuksen historiaa ja kehittymistä tieteenalana ja yhteyttä myös sosiolingvistiikkaan ennen 1990- ja 2000-lukuja kirjoittaja käsittelee niukasti. Työstä puuttuu niin ikään Geen (1999) esittelemä jaottelu diskurssikäsitteen ahtaampaan (discourse) ja laajempaan (Discourse, "Big-D") määrittelyyn, jonka avulla tekstitason ja laajemman sosiaalisen kontekstin suhdetta olisi voinut vielä valottaa väitöskirjan tutkimuskohteen ja metodien kannalta. Lisäksi yhtymäkohdat kriittiseen diskurssintutkimuksen teoriaan olisivat kaivanneet tukevoittamista - mikäli kirjoittaja tosiaan haluaa kytkeä lähestymistapaansa myös kriittisen otteen. Sinänsä on toki ymmärrettävää, että työn monitieteisyyden vuoksi teoreettista taustoittamista on jouduttu rajoittamaan.

Kiinnostavaa ja innovatiivista on, että Lehto sekä soveltaa korpusavusteisia menetelmiä aineistoonsa että testaa niitä. Korpusanalyysi rajaa tarkasteltavan aineiston ikkunanpuitteiden lailla yhteen näkymään, jonka paljastamia diskursseja tarkastellaan ja analysoidaan lähemmin. Korpusmenetelmin haetaan aineistosta toistuvuutta ja systemaattisuutta, joka saattaisi diskurssianalyyttisessä lähiluvussa olla muutoin hankalasti hahmottuvaa. Lehto viittaa lisäksi korpusmetodien ja diskurssintutkimuksen kielikäsitysten ja taustaoletusten ristiriitaan, joka toimii työn metodisen vuoropuhelun polttoaineena. Väitöskirjassa korostuu kuitenkin diskurssintutkimuksen teoreettinen taustoitus, joka tarkastelee kielenkäyttöä sosiaalisena toimintana, ja korpusmetodien kielikäsitykset jäävät enemmänkin lukijan pääteltäväksi.

\section{Tulokset ja luotettavuus}

Lehdon väitöskirjaa ei ole tarkoituksenmukaista arvioida yhden tieteenalan, diskurssintutkimuksen tai sosiolingvistiikan näkökulmasta, saati ainoastaan korpusavusteisten menetelmien kautta. Yhdistämällä nämä kaikki ainutlaatuiseen japaninsuomalaisten puhuttuun aineistoon tutkimus tarjoaa uusia lähestymistapoja niin kvalitatiivisten kuin kvantitatiivistenkin menetelmien soveltajille. Käsillä on moninäkökulmainen tutkimus, joka on vaatinut laajaan ja monitieteiseen tutkimuskirjallisuuteen perehtymistä.

Aineisto on hyvin dokumentoitu, ja sen käsittely, luokittelu ja analyysi on tarkkaa; Lehto esittää perusteltuja tulkintoja ja kypsää pohdintaa. Toisaalta työ ei tarjoa paljoakaan yleistettäviä tuloksia laajemmassa sosiolingvistisessä superdiversiteetti-kontekstissa, sillä se rajoittuu mikrotason analyysiin ja pieneen mutta hieman heterogeeniseen informanttiryhmään. Tutkimus onnistuu kuitenkin osoittamaan korpusavusteisen metodin hyödyt diskurssien analyysissä: korpusanalyysi estää tutkijaa luottamasta liiaksi omiin ennakko-oletuksiinsa, ja vastaavasti korpusanalyysin esiin nostamat seikat tulevat laadullisesti analysoiduiksi. Tämä innovatiivinen metodologinen vuoropuhelu on sekä työn vahvuus että rajoite. Varsin perinteisin keinoin kerätty puhutun kielen 
erikoiskorpus saa kvantitatiivisen käsittelyn ennen kvalitatiivista analysointia ja tulkintaa. Menetelmän työläyden vuoksi aineiston käsittelyä on kuitenkin ollut rajattava. Kysymykseksi jääkin, mitä 24 tunnin laajuisesta haastatteluaineistosta jää tällä lähestymistavalla ja menetelmällä katveeseen tai käsittelemättä. Tätä kysymystä varten tutkija avannee uusia ikkunoita tulevaisuudessa.

Koska työ on tehty fennistiikan viitekehyksessä, se ei esittele japaninkielistä tutkimuskirjallisuutta eikä pohdi "länsimaisen" monikielisyys-käsitteen taustalla usein lymyävää yksikielisyysnäkökulmaa (ks. Coulmas 2018). Lehto pyrkii toki hyödyntämään kriittistä tutkimusotetta mutta ei pääse silti eroon ensisijaiseksi oletetusta yksikielisyydestä. Japaninkielinen tutkimuskirjallisuus olisi tarjonnut huomattavasti laajemman taustan ja kontekstin siirtolaisuuden, maahanmuuton, monikulttuuristumisen ja monikielistymisen tarkastelulle sosiolingvistisessä kehyksessä (ks. esim. Sanada \& Shōji 2005; Tagengoka genshō kenkyūkai 2013). Silti Lehto onnistuu tuottamaan olennaista uutta, uraauurtavaakin tietoa japaninsuomalaisten kieliin liittämistä merkityksistä, rooleista ja ajatuksista Japanin monikielistyvässä yhteiskunnassa.

\section{Sitkeät kielidiskurssit}

Väitöskirjan loppuluvussa Lehto esittelee tiiviisti keskeiset havaintonsa kielidiskursseista. Kiinnostavaa on, että vaikka informantit korostavat kielitaitoa, kielenmuutosta ja kielellisten valintojen kontekstuaalisuutta, he tuovat esiin suomen kielen yhteyden minuuteen, tunteisiin ja itseilmaisuun. Tutkimus osoittaa myös, että kielidiskurssit ovat luonteeltaan hyvin yleisiä. Esimerkiksi käsitys suomen kielen vaikeudesta tulee toistuvasti esiin. Samaan tapaan sitkeässä on arvottava kielipuhe: kielestä puhuminen kääntyy toistuvasti puheeksi kielitaidosta ja sen hyvyydestä.
Loppuluvun toisessa osassa Lehto arvioi työnsä menetelmiä. Hän huomauttaa ansiokkaasti puutteista ja katvealueista, joita ei rajatun korpuksen perusteella pystynyt tässä tutkimuksessa tavoittamaan.

Se, miten tutkimuksen kohteena olevat kielet, suomi, japani ja englanti sekä mahdolliset muut kielelliset resurssit, käytännössä realisoituvat haastateltujen japaninsuomalaisten jokapäiväisessä elämässä, jää korpusavusteisen metodin myötä pitkälti pimentoon ja olisi erittäin kiinnostava jatkotutkimuskohde. Työn liitteistä löytyvä raakadata suorastaan kutsuu havainnoimaan jokapäiväisiä kielenkäyttötilanteita. Lehdolla onkin loppusanoissaan jo seuraavat tutkimusaiheet mietittynä; siirtolaisperheiden kielipolitiikka ja siirtolaisten osallisuus yhteiskunnassa kielen kautta. Väitöskirjaa varten kerätty aineisto antaa lähtökohtia myös tällaiselle jatkotutkimukselle, jonka voi olettaa laajentavan transnationaalisuuden ja superdiversiteetin käsitteisiin linkittyvää ymmärrystämme. Siirtolaisten, maahanmuuttajien, pakolaisten, turvapaikanhakijoiden ja muiden liikkujien osallisuus yhteiskunnassa on ajankohtainen tutkimusaihe, jolla on suoria yhteyksiä paitsi kielenkäyttäjiin ja kielenoppijoihin yksilötasolla myös yhteiskunnalliseen makrotasoon Suomen ja Japanin kaltaisissa nopeasti ikääntyvissä kansakunnissa.

PirJo HiIDENMAa

RIIKKA LÄNSISALMI

etunimi.sukunimi@helsinki.fi

Tietokirjallisuuden professori Pirjo Hiidenmaa oli Lehdon väitöskirjan esitarkastaja ja dosentti Riikka Länsisalmi oli vastaväittäjä.

\section{Lähteet}

Blommaert, Jan - RAmpton, Ben 2011: Language and superdiversity. - Diversities 13(2) 1-21. 
Blommaert, Jan - Backus, Ad 2012: Superdiverse repertoires and the individual. - Tilburg Papers in Culture Studies 24 s. 1-32. https://www.tilburguniversity. edu/research/institutes-and-researchgroups/babylon/tpcs/download-tpcspaper-24.pdf.htm (15.4.2019).

Coulmas, Florian 2018: An introduction to multilingualism. Language in a changing world. Oxford Textbooks in Linguistics. Oxford: Oxford University Press.

Gee, James Paul 1999: An introduction to discourse analysis. London: Routledge.
Sanada, Shinji - Shōji, Hiroshi (toim.) 2005: Nihon no tagengo shakai [Japanin monikielinen yhteiskunta]. Tokio: Iwanami Shoten.

Tagengoka genshō kenkyūkai [Monikielistymisen tutkimusseura] (toim.) 2013: Tagengo shakai nihon. Sono genjō to kadai [Japani monikielisenä yhteiskuntana. Nykytilanne ja tutkimuskysymykset]. Tokio: Sangensha.

Vertovec, Steven 2007: Super-diversity and its implications. - Ethnic and Racial Studies 30 s. 1024-1054. https://doi. org/10.108o/01419870701599465.

\section{Pohjoisgermaanin ja itämerensuomen äännehistoriallisten ilmiöiden selityksiä täydentävä väitöstutkimus}

\author{
Johan Schalin: Preliterary Scandinavian \\ sound change viewed from the east. \\ Umlaut remodelled and language contact \\ revisited. Nordica Helsingiensia 54. \\ Helsinki: Helsingin yliopisto 2018. $411 \mathrm{~s}$. \\ ISBN 978-951-51-4387-7.
}

Teologian maisteri Johan Schalin väitteli yllä mainittua nimeä kantavalla artikkeliväitöskirjalla pohjoismaisten kielten oppiaineessa Helsingin yliopistossa syyskuussa 2018. Schalinin väitöskirja käsittelee ensisijaisesti skandinaavisten kielten äännehistoriaa ja kielikontakteja itämerensuomalaisiin kieliin 200-luvulta jKr. 1200 -luvulle jKr. (s. 5). Täten väitöskirjalla on relevanssia myös (itämeren-) suomen varhaishistorian tutkimukselle. Väitöskirja koostuu viidestä tutkimusartikkelista sekä yhteenveto-osiosta. Yksi tutkimusartikkeleista on yhteisjulkaisu folkloristi, dosentti Frogin kanssa. Väitös- kirja on enimmäkseen englanninkielinen, mutta siihen sisältyy yksi ruotsinkielinen artikkeli, laaja ruotsinkielinen tiivistelmä sekä lyhyt suomenkielinen tiivistelmä. Kantaskandinaavin ja jossain määrin kantasuomen äännehistoriaa käsittelevän väitöskirjan kielivalintoja voinee pitää perusteltuina, sillä suomalaisen tiedeyhteisön ruotsin kielen taito on vaihteleva ja skandinaavisessa tiedeyhteisössä suomen kielen taito on harvinainen.

Kantaskandinaavista (n. 100-700 jKr.) on omaksuttu lukuisia lainasanoja itämerensuomeen ja saameen, ja lisäksi se on jättänyt jälkeensä myös suoria kielenmuistomerkkejä erilaisiin materiaaleihin kaiverrettujen riimukirjoitusten muodossa. Kyse ei siis ole likimainkaan vain rekonstruoidusta kielimuodosta. Asiaa tuntematon lukija saattaa kuitenkin saada vastakkaisen käsityksen väitöskirjan nimen ensimmäisestä sanasta preliterary. 